\title{
Use of Catheter-Controlled Thrombolysis in the Treatment of Patients with Acute Thrombosis of Deep Veins of the Lower Extremities
}

\author{
Boyko VV, Taraban IA*, Prasol VO and Okley DV \\ Zaytsev Institute of General and Urgent Surgery, Ukraine \\ *Corresponding author: Taraban IA, Zaytsev Institute of General and Urgent Surgery, Kharkiv, Ukraine
}

\begin{tabular}{ll} 
ARTICLE INFO & ABSTRACT \\
\hline
\end{tabular}

Received: 蔧 June 22, 2019

Published: 慧 July 01, 2019
Abbreviations: VTEU: Venous Thromboembolic Complications; PTH: PostThrombotic Disease; CCT: Catheter-Controlled Thrombolysis

Citation: Boyko VV, Taraban IA, Prasol VO, Okley DV. Use of Catheter-Controlled Thrombolysis in the Treatment of Patients with Acute Thrombosis of Deep Veins of the Lower Extremities. Biomed J Sci \& Tech Res 19(2)-2019. BJSTR. MS.ID.003276.

\section{Opinion}

Venous thromboembolic complications (VTEU), which include deep vein thrombosis (TGV) and pulmonary embolism (TIA), are a topical problem in modern medicine due to one of the frequent causes of mortality and disability [1-3]. In Ukraine annually there are about 260 cases of deep vein thrombosis and their complications per 100000 population with a fatality rate of TSE at the level of 20$25 \%$ [4]. When involved in the thrombotic process of the proximal segment of the veins of the lower limb, irreversible damage to the valvular apparatus of the vein, resulting in venous dysfunction and, subsequently, the development of post-thrombotic disease (PTH). Despite the existence of a large arsenal of effective anticoagulants and the use of modern antithrombotic regimens, $30-75 \%$ of patients in the remote period have HRT of varying degrees of severity, and $10-40 \%$ of them suffer from severe edema of the lower extremities, chronic pain and / or trophic ulcer, which leads to persistent signs of disability $[5,6]$. Thus, in the structure of primary disability due to diseases of the veins of the lower extremities, the consequences of postponed VTEU make up $77.4 \%$ of cases [7]. In this regard, the tactics of treating patients with proximal DVT remains the subject of active discussion both in our country and abroad [8].
Today, thrombolytic therapy is an alternative treatment for acute thrombosis in the system of the lower vena cava, which is indicated in the recommendations of the American College of Thoracic Physicians [9-11]. According to interdisciplinary clinical guidelines - "Venous thromboembolism: diagnosis, treatment, prevention", Kyiv, 2017. - the use of systemic thrombolysis in DVT promotes a reduction in the frequency of relapsing DVT and PTX. According to randomized trials, for systemic use of streptokinase, the function of venous valves was better than with heparin [11]. In a review of 6 clinical trials, systemic thrombolysis was 3.7 times more effective than heparin. In a combined analysis of 13 randomized trials, only $4 \%$ of patients who received heparin achieved significant or complete lysis, after systemic administration of streptokinase - $45 \%$. However, prolonged infusion of streptokinase is often the cause of the occurrence of allergic reactions and hemorrhagic complications - 3 times more often than in patients who were prescribed heparin. In addition, the frequency of satisfactory lysis of blood clots is not high enough to make positive conclusions about the use of systemic thrombolysis. 
Studies have shown that systemic administration of thrombolytic agents in the widespread occlusive thrombosis of deep veins is ineffective, probably due to the lack of contact area of the drug with thrombotic masses in conditions of disturbed regional hemodynamics $[12,13]$. This fact played a decisive role in the increasingly frequent use of regional thrombolysis instead of systemic administration of the thrombolytic drug. Further research in this direction led to the development of the method of catheter-controlled thrombolysis (CCT), with the introduction of which in clinical practice there was an opportunity to restore the permeability of deep veins in $80 \%$ of patients without increasing the amount of bleeding $[12,14,15]$. Direct streptokinase catheter therapy for proximal DVT provided complete thrombus lysis in $72 \%$ of patients for concomitant symptom relief. The selective delivery of a thrombolytic agent allows for a high concentration of substance within the thrombus, which would be impossible provided it is systemic [1]. Due to this, catheter-controlled thrombolysis is increasingly used as a method of choice in the treatment of patients with proximal phlebothrombosis [11,16-17].

\section{References}

1. (2014) ISTH Steering Committee for World Thrombosis Day Thrombosis: a major contributor to global disease burden. Thromb Res 134(5): 931-938

2. Heit J A (2015) Epidemiology of venous thromboembolism. Nat Rev Cardiol 12(8): 464-474.

3. (2015) Venous thromboembolism: the effectiveness of diagnosis and provision of medical care in modern conditions / B.M. Todurov, AI Yanchik, GI Kovtun [and others]. Ukrainian Cardiology Magazine 6: 2532.

4. (2012) Long-term results of treatment of acute venous thrombosis of the femoral-club segment / O. B. Kutovy, 00 Sergeyev, O.I. Abramova [and others.]. Clin Phlebology 5(1): 55-57.

5. Mahan CE, Barco S, Spyropoulos AC (2016) Cost-of-illness model for venous thromboembolism. Thromb Res 145: 130-132.

6. E Yu Soldatsky, SM Yumin, KR Khabazov (2014) Long-term results of treatment of deep vein thrombosis of the lower leg and femoral-popliteal segment. Flebologiya 1: 40-48.

\section{ISSN: 2574-1241}

DOI: 10.26717/BJSTR.2019.19.003276

Taraban IA. Biomed J Sci \& Tech Res

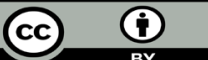

This work is licensed under Creative

Commons Attribution 4.0 License

Submission Link: https://biomedres.us/submit-manuscript.php
7. Kearon C, Akl EA, Comerota AJ, Prandoni P, Bounameaux H, et al. (2012) Antithrombotic therapy for VTE disease: antithrombotic therapy and prevention of thrombosis, $9^{\text {th }}$ (edn.). American College of Chest Physicians Evidence- Based Clinical Practice Guidelines. Chest 141(2Supply): 419-940.

8. Meissner MH, Gloviczki P, Comerota AJ, Dalsing MC, Eklof BG, et al. (2012) Early thrombus removal strategies for acute deep venous thrombosis: clinical practice guidelines of the Society for Vascular Surgery and the American Venous Forum. J Vasc Surg 55(5): 1449-1462.

9. Comerota $\mathrm{AJ}$ (2015) Catheter-directed thrombolysis for iliofemoral deep vein thrombosis: helpful or hurtful? Expert Rev Hematol 8(2): 131-133.

10. Haig Y, Enden T, Slagsvold CE, Sandvik L, Sandset PM, et al. (2013) Determinants of early and long-term efficacy of catheter-directed thrombolysis in proximal deep vein thrombosis. J Vasc Interv Radiol 24(1): 17-24.

11. VN Boyko, PI Bolidzhar, IK Wenger (2017) Ukrainian interdisciplinary clinical guidelines for the prevention, diagnosis and treatment of venous thromboembolic complications. Clinical phlebology 10(1): 42-104.

12. Bækgaard N, Klitfod L, Jørgensen M (2016) Should catheter-directed thrombolysis be monitored? Phlebology 31(1Supply): 5-10.

13. GH Xue, XZ Huang, M Ye, JW Zhang, BG Zhang, et al. (2014) Catheterdirected thrombolysis and stenting in the treatment of iliac vein compression syndrome with acute iliofemoral deep vein thrombosis: outcome and follow-up. Ann Vasc Surg 28(4): 957-963.

14. Prasol VA, EV Mishenina, DV Okley (2015) Tactics of management of patients with ongoing deep vein thrombosis. Klinichna khirurgiya 3: 3638.

15. Lu T, Loh TM, El Sayed HF, Davies MG (2017) Single-center retrospective review of ultrasound-accelerated versus traditional catheter-directed thrombolysis for acute lower extremity deep venous thrombosis. Vascular 25(5): 525-532.

16. Lin M, Hsieh JCF, Hanif M, McDaniel A, Chew DK (2017) Evaluation of thrombolysis using tissue plasminogen activator in lower extremity deep venous thrombosis with concomitant femoral-popliteal venous segment involvement. J Vasc Surg Ven Lymph Disord 5(5): 613-620.

17. Gombert A, Gombert R, Barbati ME, Bruners P, Keszei A, et al. (2018) Patency rate and quality of life after ultrasound-accelerated catheterdirected thrombolysis for deep vein thrombosis. Phlebology 33(4): 251 260.

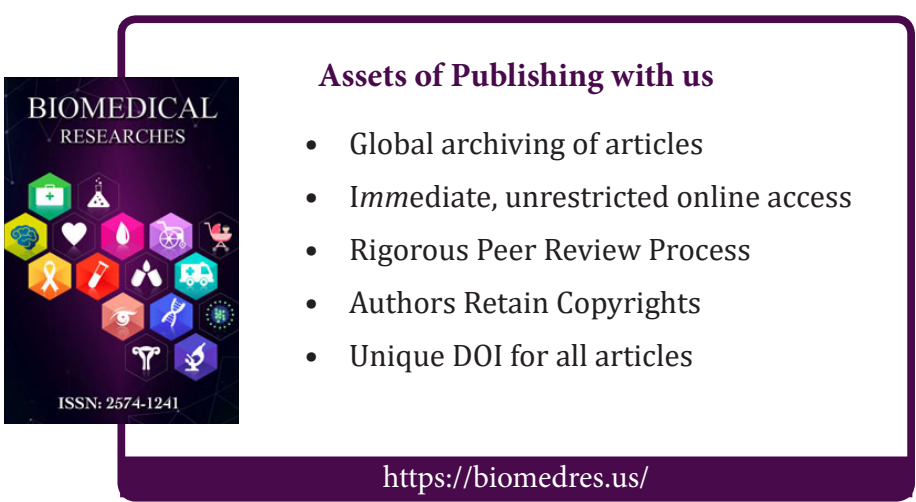

